\title{
Language, Memory, and Sense Perception in the Religious and Technological Culture of Antiquity and the Middle Ages
}

\author{
Werner H. Kelber \\ The Albert Lord and Milman Parry \\ Lecture for 1993-1994
}

... major developments, and very likely even all major developments, in culture and consciousness are related, often in unexpected intimacy, to the evolution of the word from primary orality to its present state. But the relationships are varied and complex, with cause and effect often difficult to distinguish.

(Ong 1977:9-10)

The two persons in whose honor this lecture is named were North American classicists of eminence who had acquired additional training in the oral traditional epics of the former Yugoslavia, an achievement unequaled among scholars of their time. Long before interdisciplinary studies had come into scholarly and curricular vogue, Milman Parry and Albert Lord had attained a literacy in comparative studies that was both severely academic and daringly imaginative. Almost singlehandedly, they initiated the distinct academic field of oral traditional literature, which concerns itself with the study of compositional, performative, and aesthetic aspects of living oral traditions and of texts dependent on oral tradition. Strictly speaking, the work inaugurated by Parry and Lord, and energetically carried forward by John Miles Foley, aspires to a new poetics informed by our growing knowledge of oral tradition. By now the field has grown into a scholarship that cuts across a wide spectrum of the humanities and social sciences, bridging national and religious boundaries and encompassing the multicultural body of the human race. 
Broadly speaking, the impact of Parry and Lord extends beyond the subject matter of oral tradition. The rediscovery of a culture of speech in the Western tradition has in turn encouraged reflection on the nature of texts, exposing a dominantly post-Gutenberg mentality within classical, biblical, and medieval studies. To a growing number of scholars who are proficient in the field of oral traditional literature, it is evident that there is something different about many of our classical texts, and our conventional reading of them, than most branches of current literary criticism would let us know. Oral and orally dependent texts were tradition-bound, variously interfacing with orality and other texts, and deriving meaning from extra-textual signifieds no less than from internal signification. "What we are wrestling with," Foley has suggested, 'is not just 'mechanism' versus 'aesthetics,' not just 'oral' versus 'literary,' but an inadequate theory of verbal art" (1991:5). Eric Havelock (1963, 1982) and Walter Ong (1967, 1982, 1983), whose work likewise came to focus on the culture of orality, pursued still broader avenues into philosophical, intellectual, and religious history. Today, the field commonly referred to as orality-literacy studies challenges us to rethink a set of concepts we thought we had known for certain. Text and intertextuality, author and tradition, reading and writing, memory and imagination, logic and cognition-these central metaphors of Western thought - are all affected by the study of oral traditions and a chirographic culture interacting with them. We begin to see-as if through a glass darkly - the broader implications of Parry's and Lord's scholarship for understanding our cultural heritage.

This essay will not consider the technicalities and aesthetics of oral traditions per se. I shall pay homage to Parry and Lord by developing across ancient and medieval culture some implications of the intellectual project they initiated. The broad and rather sweeping scope of the essay does not aspire to another metahistory, for I share postmodernism's anxiety about the futility (and vanity) of global narrative ambitions. History resists assimilation to single research paradigms. But in reinvesting imaginatively the interdisciplinary endowment of Parry and Lord, I seek to identify issues of longstanding and persistent urgency resonating across the religious and technological culture of our ancient and medieval past. 
"Speech is a powerful ruler." 1 With these words, the fifth-century Sophist, rhetor, and rhetorician Gorgias invoked what for him was the critical issue of language. Ostensibly, the idea of language he had in mind was shaped by the media conditions of his culture. The logos was perceived here neither as sign nor signification, and not as carrier of meaning or revealer of truth, but rather as a potent ruler intent on governing his subjects. Gorgias' idea of the logos flowed directly from the experience of oral speech. Language was perceived to be a force, orally processed and operative in relation to hearers. This theme enunciated by Gorgias retained its hold on Western culture, bequeathing to it a myriad of linguistic, philosophical, and political problems.

True to the oral, rhetorical epistemology, Gorgias advocated an approach to language that comes close to the one we have recently rediscovered in terms of receptionist theory. What interested him primarily about speech was not the processes of verbal composition, but the aesthetics of reception. "Of logoi some give pain, some pleasure, some cause fear, some create boldness in hearers, and some drug and bewitch the soul by a kind of evil persuasion." 2 The arousal of pain and pleasure, of fear and pity are the primary objective of the logoi. Among words Gorgias singled out the metered language of the poetic tradition, which effected fearsome horrors, tearful sympathies, and melancholic desires (Helen:9). He did not entirely dismiss the rational aspects of speech. Occasionally he would attend to speech as technê, an acquirable art. But his main interest lay in the elaboration of a psychology of the emotive powers of oral communication. The efficaciousness of words meshed with the form of the soul, impacting it, molding it, and converting it. It was this affective persuasion of the soul that lies at the heart of Gorgias' theory of language.

The alliance Western culture has forged with the powers of oral speech is an addictive but uneasy one. Gorgias himself introduced the

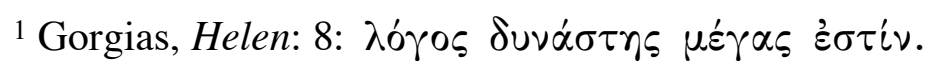

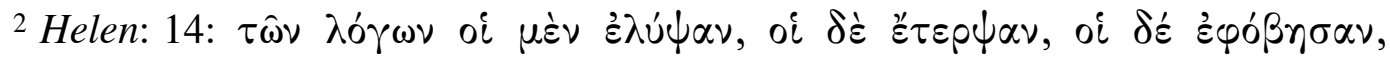

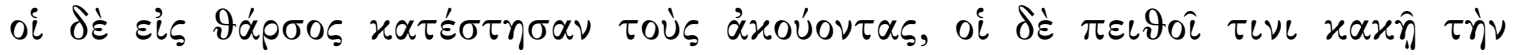

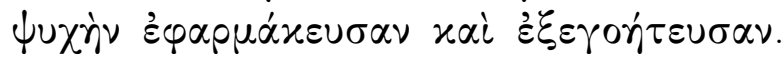


celebrated metaphor of the pharmakon. The power of words affects the soul as the drug does the body (Helen:14). In speech, the processes of healing and poisoning were mysteriously mingled, swaying the psychic condition for better and for worse. Under the powerful spell of speeches, the soul was likely to be cured or deceived. The worst possible scenario, and one Gorgias was keenly aware of, was the use of words for flattery, manipulation, and the fulfillment of personal longings for power. The principal characterization of this aspect of speech was deception (apatê). It was a stigma that would cling to the powers of speech from antiquity to modernity. Pressed for an explanation for this ambiguous operation of oral language, Gorgias invoked the realm of magic and religion. The spell of words, especially poetic words, was perceived to be closely allied with magic and witchcraft (cf. de Romilly 1975). Poetic performances, the stirrings of passion, and the conversion of the soul escaped rational probings. Divine both in origin and in their inspirational effect, they created a godlike trance (enthousiasmos) among hearers. Speech thus put into effect by accomplished oral practitioners was a form of divine madness.

It bears repeating that the principal problematic of language-as viewed by Gorgias - was not meaning, but power. How did one cope with the poetic powers that drew their sustenance from divine resources? Should speech be liberated from its seductiveness and channeled into the paideia of truth and wisdom? How could the awesome powers of magical, inspirational speech be harnessed and integrated into a viable educational program? How destructive a force was language untamed by method and technê? Clearly, the issue was that language presented itself in terms of force and effect rather than with a view toward referential meaning, structure, or signification.

Once we recognize the importance attributed to language as power, and the duplicity of language in terms of healing and poisoning, Plato himself and his philosophical project begin to take on novel meaning. It was Havelock's signal humanistic achievement to have relocated the master philosopher into the broad cultural context of a technological and intellectual revolution in antiquity $(1963,1978,1982)$. Propelled by the invention of the "explosive technology" of the Greek alphabet (1982:6), a literate consciousness was ushered in that challenged the millennial tradition of poeticized, recitable language - the language of power and magic. In that age of sweeping cultural changes, Plato's dialogues both accelerated the 
collapse of tradition-honored habits and endeavored to explore alternative ways of understanding. The philosopher lived "in the midst of this revolution, announced it and became its prophet" (Havelock 1963:vii). Poised between the ancien régime of the poets and the literate technology of a new age, he articulated a moral and intellectual program that assimilated the reorganization of culture and consciousness.

When Plato refused to admit the poets into his well-ordered state (Rep. 605b 607b), he pointed to the emotive and magical impact of their words. He did not mind telling his audience that what it was applauding in the theater was the conduct of a woman, whereas men had learned to retain control over their passions (Rep. 605d, e). His chief objection, however, did not rest on the problematic linking of poetic emotions with gender, but on the issue of mimêsis. The mimetic art practiced by "friend Homer" (Rep. 599d) and his fellow poets corrupted the soul and destroyed its rational part by fashioning phantoms removed from reality. The poeticized tradition and experience of rhythmic and emotional spells so necessary to the act of identification was a kind of "psychic poison" (Havelock 1963:5). Plato's targets, Havelock came to realize, were the dramatic performances and the audio-visual group experience of audiences, and the degree to which this theatrical mentality indoctrinated a plurality of views about justice and the good held by the many. Had Homer been able to truly educate the people, he would have "possessed not the art of imitation but real knowledge."3

Plato himself lacked the temporal distance to appreciate the cultural, linguistic implications of his tirade against the Homeric poetic tradition. It was Havelock's illuminating work on Plato (1963) that explicated mimêsis in terms of a millennial experience of oral performing and traditioning. Shaping language in rhythmic, memorable fashion and composing it via the oral processes of imitation, the poets encouraged recitation and learning through repetition, as well as emphatic participation. But as far as Plato was concerned, knowledge acquired by imitation, repetition, and empathy was of little value. What mattered was to determine "what each thing really is," 4 a new type of mental activity clearly envisioned as a conversion away from plural impressions toward the abstracted object and timeless truth.

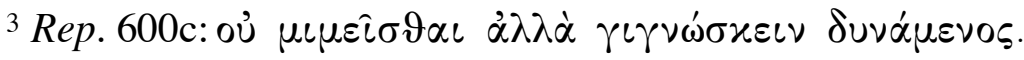

${ }^{4}$ Rep. 533b. ò है $\sigma \tau \iota \nu$ हैx $\alpha \sigma \tau o \nu$.
} 
For the philosophical purpose of Platonism was "to accelerate the intellectual awakening which 'converts' the psyche from the many to the one, and from 'becomingness' to 'beingness"' (Havelock 1963:258-59). This new type of intellectual activity was related to the methods of mental storage that had undergone changes since the time of the Homeric bards. Alphabetic literacy not only distanced the individual from the tribal encyclopedia, it also freed the mind to entertain thoughts apart from and even against it. Plato's resentment against the poets could thus well be understood as a revolt of the literate mentality against the oral traditional hegemony of Homeric poetic culture.

Although Plato's philosophy was a beneficiary of the rationalizing effects brought about by the alphabetization of the Greek language and of chirography, the philosopher could not bring himself to embrace the new medium as a matter of principle. While availing himself of the new chirographic technology, he lamented its corrosive effects on memory, discourse, and culture generally, basing his objections on a thoroughly oral apperception of language. Writing, far from assisting memory, implanted forgetfulness into our souls (Phaedr. 275a). Written words were antisocial, because they segregated themselves from living discourse. Like paintings, writings "maintain a solemn silence": they stare at readers, telling them "just the same thing forever." 5 Chirographic products were rather like children who had lost their parents and were unable to defend themselves. Plato knew that it was the inevitable fate of writings to fall into the hands of the wrong people (Phaedr. 275e). Writing, finally, was an unacceptable exteriorization of thought that only gave the appearance of wisdom (Phaedr. 275a). These were all arguments characteristic of a mind deeply versed in oral culture, distrustful of the harmful influence of writing and committed to the living, dialogical, and interiorizing powers of speech.

Poetic speech aside, what would Plato have to say about nonpoeticized, oral speech that by his time came to be called rhetoric? On this matter he joined Gorgias in denouncing speakers who "steal away our souls" 6 with their embellished words and whose flattery sends us to the "Islands of the Blessed." 7 Rhetoric simply as a producer of persuasion was

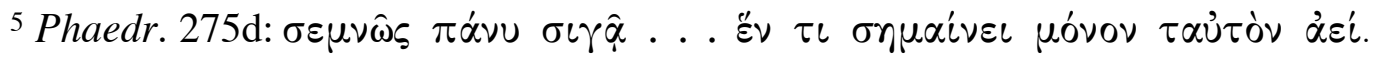

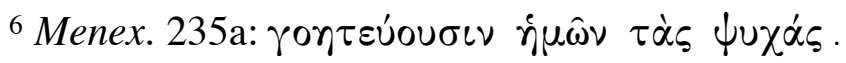

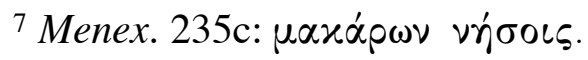


hostile to an environment that nourished discourse and dialogue. Ask any of our proficient speakers about their words, he exclaimed in a state of exasperation, and they will give us more speeches of the same: "like books they cannot either answer or ask a question on their own account." 8 The "art of oratory" 9 is no art at all if it is practiced by one who is "chasing after beliefs, instead of knowing the truth." 10 Rhetoric's basic flaw was thus its inability to enlist words in the search for truth.

Resentful of the magical powers of speech, in revolt against the poetic mentors of ancient Greece, and distrustful as well toward the new technology of writing, Plato redefined the oral, rhetorical tradition in terms of dialectic. One of its objectives was to keep words alive in the flow of discourse and to forestall ideational sedimentation. Unfettered by scribal constraints and mimetic routine, dialectic availed itself of the oral mode of communication, which was flexible enough to facilitate replacement of anything with something else, should the need arise. But it was a "discourse of reason," 11 distanced from Gorgias' magical comprehension of speech, and unthinkable without the rationalizing effects of writing. Dialectical reasoning isolated and defined subject matters, divided and subdivided them until "it reached the limit of division." 12 Proceeding in this analytic fashion, it aspired to lead the soul away from the particulars and toward the contemplation of "the very essence of each thing." 13

One of the most revolutionary aspects of the Platonic dialectic was its ambition to arrive at the nature of things "apart from all perceptions of sense." 14 The person most likely to succeed was one whose soul was "free

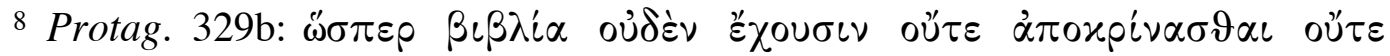

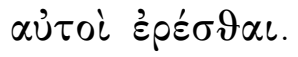

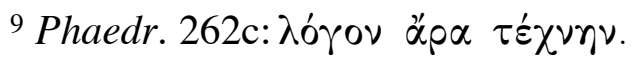

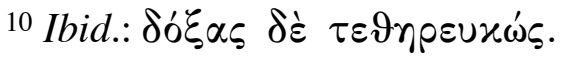

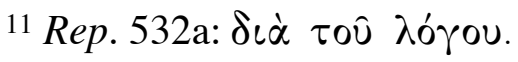

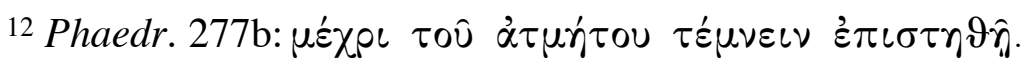

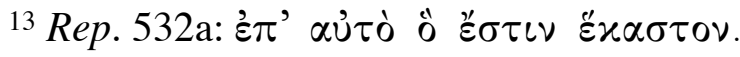

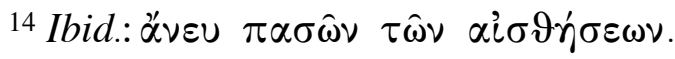


of all distractions such as hearing or sight or pain or pleasure of any kind"15 and eager to pursue the truth "by applying his pure and unadulterated thought" 16 to the object of thought. The quest for knowledge was to be transacted "by thought itself," 17 as it were. These were ideas no longer in keeping with the affective persuasion of words and the divine madness they created among hearers; they were diametrically opposed to the cultural mindset of Homeric orality. Language was thereby transformed into a catalyst of cognition, displacing the oral powers both of emotive incitement and rhetorical persuasion.

Viewed in the context of a cultural revolution, Plato's dialectic endeavored to forge a middle way. It sought to retain the medium of speech, while effecting its domestication in the interest of logic. As a consequence, rhetoric's " "savage' roots" were severed (Ricoeur 1977:10), and oratory was subjected to the discipline of philosophical reasoning. Oral discourse written into the soul of the listener remained a viable procedure, but it was discourse tamed by the logical restraints of dialectical reasoning. In late antiquity and in the Middle Ages, the dialectic tradition came to be situated between rhetoric on one hand and logic on the other, whose conflictual relationship constituted a deep and enduring problematic in the Western tradition.

Plato's daring project to purify thought by the exclusion of the senses flies in the face of ancient theories of knowledge. For it was widely understood that orality and rhetoric, as well as the art of scribality, engaged the human sensorium and played the sensory register in the interest of retention, emotive incitement, and persuasion. Ong's phenomenology of culture and consciousness has furnished ample evidence of the oral affinity between sound and thought (1967:111-75). What must be added is that the processes of knowledge were transacted by analogy with seeing no less than with hearing. Both vision and voice were sense analogues for the intellect. That one should "disregard the eyes and other senses and go on to being

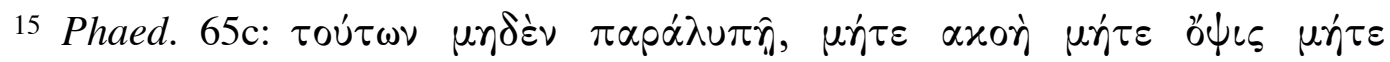

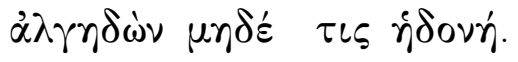

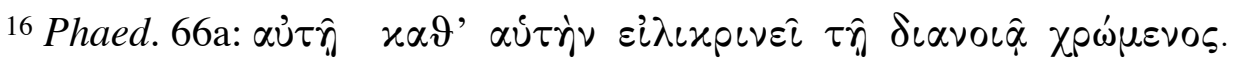

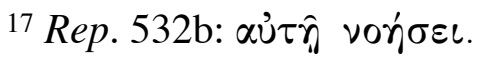


itself in the company with truth," as Plato would have it, ${ }^{18}$ remains a revolutionary but passing reference in ancient philosophical discourse. For the exclusion of the human sensorium from the pursuits of knowledge was largely unthinkable in ancient and medieval intellectual culture.

Indeed, Plato cannot dishabituate himself from visual metaphors altogether. His language is replete with image analogues: eikon, eidolon, phantasma, homoioma, mimema (Patterson 1985:30). For example, he would postulate the presence of an internal painter who draws into our soul pictures of assertions we make (Phil. 39b). More importantly, he defined the highest form of cognition as a vision (eidos) of the soul liberated from all earthly chains and ready to contemplate the real and the true (Rep. 518c519a). To obtain this view of the good, the soul has to be converted and its vision redirected "from the world of becoming to the world of being." 19 Whether the vision is internalized or outer-directed, there is a form of seeing no less than hearing that serves as an agent of cognition.

A locus classicus for sense perception was memory, the esteemed "treasure-house of eloquence." 20 Long before the art of memory was assigned a place of honor in rhetoric, its significance was already recognized in mythology. According to myth, Mnemosyne, the goddess of memory, bore Zeus nine daughters, the Muses, who personified different modes of poetry, the arts, and sciences. An imaginable female, a corporeal similitude herself, the goddess embodied memory. Her daughters, who carried the attributes of wax tablet and pencil, the flute and lyre, the tragic and comic mask, the scroll and a celestial globe, represented a civilization that was constituted by writing and music, the tragic performance and comedy as well. But whether they facilitated sound or vision, speech or writing, they always functioned as the daughters of Mnemosyne. As mother of the Muses, she was the origin of all civilized labors and a wellspring of culture. Memory, not textuality, was the centralizing authority. Only a civilization conscious of and dependent on oral modes of communication and thought could have produced this myth of Mnemosyne and the Muses.

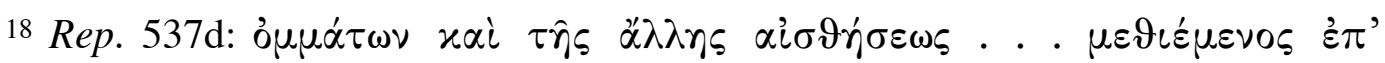

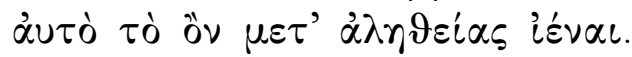

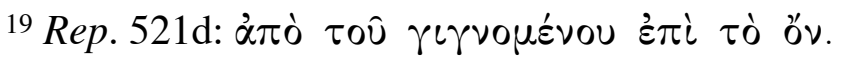

${ }^{20}$ Quintilian, Inst. Orat. 11.2.1, et al.: thesaurus eloquentiae. 
From Aristotle we have received one of the earliest, strikingly philosophical, testimonies to memory. His treatise on Memory and Recollection introduced a key feature of memory, namely, the theory of images. Responding to external stimulation, memory retained a sense content, a visual representation of the external object. According to this principle, all our thoughts and perceptions were deposited in memory by way of images: "we cannot think without images." 21 What was actually present in memory were pictures (phantasmata) of the real things. In principle, memory could not process understanding as a function of pure thought. Even conceptual thought, Aristotle insisted, cannot exist without mental pictures. ${ }^{22}$

Apart from its mythological thematization, memory was inescapably drawn into the orbit of rhetoric. For Cicero (De Oratore 2.ixxxvi, 351-60), for the anonymous author of ad Herennium (3.16.28 - 24.40), and for Quintilian (Inst. Orat. 11.2), oratory was a subject of supreme practical value, and memory the esteemed custodian of rhetoric. In the writings of these authors the theory of memory's imagines and loci is delineated in some detail. The work of memory was conducted via images and places; these were "the stock definition to be forever repeated down the ages" (Yates 1966:6). The challenge was to create a condition that was favorably disposed to the retention of whatever one wanted to remember. First, one had to invent figures, marks, or portraits that adhered the longest in memory. Since all images required an abode, one secondly had to employ a large number of mental places, clearly defined, in orderly arrangement and separated at measured intervals. Memory thus perceived was entirely a spatial entity, like a house divided into many rooms, and its principal operative mechanism was the storing of images in those localities. Words no less than things were thought to be transmutable into images and localizable at places, although it was often recognized that the memoria verborum was more difficult to accomplish than the memoria rerum. Thus, in the work of memory, the visual nature of mental representations was widely taken for granted. "Of all the senses, sight is the keenest," ${ }_{23}$ Cicero

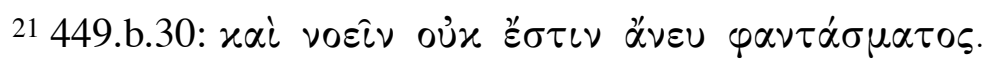

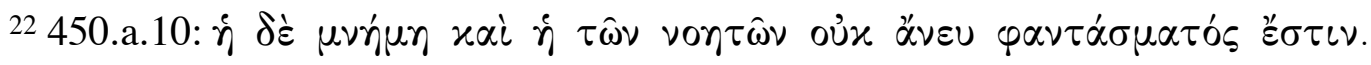

23 De Orat. 357: acerrimum autem ex omnibus nostris sensibus esse sensum videndi. 
exclaimed, extolling the cognitive superiority of vision, a theme that was going to be replayed by Aquinas, Leonardo, John Locke, and a myriad of modern thinkers. But when we consider that words such as fantasy (phantasma), imagination (imago), and rhetoric itself, essential components of the rhetorical model of cognition, have largely become pejorative terms in our time, we also recognize the changes in consciousness that distance us from our ancient heritage.

The memory tradition defied all theories of pure thought and verbocentrism. Plato's penchant for disembodied thought and desensitized vision of the good notwithstanding, ancient and medieval theories and practices of language were strongly indebted to a kind of physiology of perception (Padel 1991). It was widely assumed that both hearing and seeing mediated processes of recollection and perception. In spite of a developing chirographic culture, words were still perceived to be functioning more in the biosphere of human interaction than in the tissue of intertextuality. Knowledge took its rise from the sensorium.

Augustine, practicing rhetor and trained rhetorician himself, singled out Paul as a paragon of Christian oratory: "With what a river of eloquence [his words] flow, even he who snores must notice."24 Indeed, Paul's letters, the earliest Christian canonical literary products, operated in the mode of argumentation and with the intent of producing conviction in audiences (Bultmann 1910, Wuellner 1977, Betz 1979, Stowers 1981). If Plato was the dialectician in search of a reasonable alternative to sophistic deception and the ancien régime of oral, poetic authority, and Aristotle the analytical rhetorician making the ars rhetorica safe for philosophy, Paul was the practicing Jewish-Christian rhetor ever mindful of his message's reception in its hearers' hearts. Academic and popular wisdom, however, unaware of the ancient recognition of Paul's rhetorical skills and identity, has frequently identified him as Christianity's first self-conscious theologian. In this role he is perceived as a thinker who developed for reflection generic topics such as christology or eschatology, and who conceptualized faith, Spirit, and works. But to perceive him in this classic theological fashion is to deliver him to the time-honored rival of rhetoric, that is, to logic. While the degree of Paul's indebtedness to Jewish, Hellenistic, or Hellenistic-Jewish culture remains subject to debate, there is a

${ }^{24}$ De Doc. Chr. IV,vii,12: quanto vero etiam eloquentiae concurrerint flumine, et qui stertit advertit. 
growing realization that he did not seek the truth abstracted from the pragmatics of concrete human interaction. Increasingly we learn to see him as a master in discerning the persuasive potential of current issues and concerns, and in constructing appropriate epistolary responses.

Pauline rhetoric betrays a distinctly dialogical flavor. Its reasoning, which was adverse to descriptively dispassionate thought, evolved in argumentation with others. Historical criticism has well explained the prevailing polemics in the apostolic letters as responses, not to Judaism per $s e$, but to alternate gospel versions. Viewed from this perspective, the Pauline letters give us insights into an early situation of multiple traditions in conflict. But there is a rhetorical rationale for Paul's mode of argumentation as well. Far from admitting of any reflection on the personality of the man, his adversarial style has grown directly out of the rhetorical culture of late antiquity. Thought and convictions in this culture were born out of assertion against opposition and in discourse with other persons. One of the best known examples of Paul's dialogical reasoning was the diatribe. It was a device whereby imaginary and anonymous interlocutors posed questions, raised objections, and made patently erroneous statements, which in turn provided Paul with an opportunity to respond, correct, and state his own view on the matters in question.

The diatribe, in other words, was a rhetoric of simulated dialogue that purported to intensify contact and to lessen the distance between Paul and his audiences. Nowhere in the Pauline corpus are the interlocutory devices of the diatribe more thoroughly implemented than in Romans, the very letter that addressed a community Paul had no personal knowledge of at the time of his writing (Stowers 1981:79-184). But it is also in Romans that the idealized nature of the diatribal discourse is clearly in evidence. More than the other Pauline letters, this one lacks features of historical specificity. The fictionality of simulated dialogue in Romans is hardly incidental. It is designed to enhance communication in the very situation in which Paul lacked case-specific information.

A principal technique of apostolic persuasion was to adopt and revise key terms employed by his addressees. One remembers Socrates' advice given to Meno that in discourse we must employ terms "with which the questioner admits he is familiar." 25 Paul's thought, as it mainfests itself in his letters, proceeded in a dialectic of adoption and revision, a process that

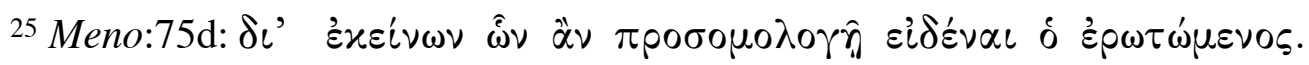


kept his language inescapably focused ad hominem. Each letter, therefore, involved readers in a different intellectual orbit and in a distinct semantic field. As a whole, the Pauline corpus presents itself as a kaleidoscopic experience, confronting readers with multiple rhetorical situations. This is a principal reason for the difficulties modern readers encounter in comprehending the apostle's letters. The casuistry of his rhetoric runs counter to theological and logical premises, prompting charges of inconsistency, even of intellectual inferiority. But rhetoric, not logic, is the key to Paul. In the words of Carruthers, rhetoric "does not normalize an occasion, it occasionalizes a norm" (1990:181). If logic considers an audience at all, it thinks of a universal audience. Paul the rhetor practices thinking in interaction with multiple audiences.

Dialectical features notwithstanding, Paul is more adequately viewed as belonging to the rhetorical rather than the dialectical tradition. True to the ethos of rhetoric, he shaped his message to preconceived ends. Knowing the rhetorical objective in advance, he cultivated the means of persuasion that were to attain the goal. His repeated pronouncements on the Law, for example, did not move from an analysis of the human plight under the Law to the solution in Christ, but rather from the experience of redemption in Christ to a reconsideration of the role of the Law. Without recognizing the full import of his discovery, E. P. Sanders had in fact defined the rhetorical nature of Pauline thought when in reference to the issue of the Law he coined the memorable phrase: "the solution precedes the problem" (1977:442). Whereas a thoroughgoing dialectic is propelled by a rigorous sifting of ideas aimed at discovering truth, rhetoric "knows its conclusions in advance, and clings to them" (Ong 1983:2). In Paul, dialectic is subsumed under rhetoric. While his argumentation is intrinsically consistent and often in keeping with midrashic norms of interpretation, it evolved out of and adhered to human life situations, and it knew its cardinal premises and conclusion in advance. The principal test of truth was loyalty to Christ, to the gospel, as well as to him, the apostolic messenger. Partiality, not objectivity, was desirable.

Paul the rhetor favored a fundamentally oral disposition toward language. ${ }^{26} \mathrm{He}$ deployed the term gospel predominantly in auditory contexts and exclusively in reference to the oral proclamation. To be effective, the gospel needed to be proclaimed and heard. The notion of

26 See espec. Kelber 1983:140-83. 
responding to his addressees by way of a written gospel narrative appears to have been entirely foreign to his mode of thinking. Hearing, not sight, was accorded a place of pride in his economy of the sensorium. It was the supersense that facilitated interiorization of sounded words and faith. Heart was the anthropological metaphor of human interiority and intentionality (Jewett 1971:305-33). It was also the central receptive organ both of the Spirit (Gal. 4:6; 2 Cor. 1:22) and the word of proclamation (Rom. 10:8). Preached words, Paul insisted, entered human hearts, engendered faith, and in turn generated confession. His media advise that "faith comes from hearing" (Rom. 10:17) contributed toward Christianity's historical commitment to the ancient oral-aural sense of words, a commitment that prevailed across the centuries in spite of progressively technologized transformations of language. If to Homer we owe the legacy of the "winged words," 27 from Paul we have received the metaphor of the light-footed word that "runs" its course, ${ }^{28}$ across the mediterranean oikoumen $\hat{e}$, carried as it were by the apostolic feet.

As is the case with all categorizations, rhetoric illuminates principal aspects of Pauline language and thought, while simultaneously masking features that lie outside the rhetorical ethos, or are in tension with it. Also present in Paul's letters is a potentially conflictual relation with rhetoric. When in 1 Corinthians the apostle castigated the "wisdom of the world" $(1: 20)$ as a strikingly oral, rhetorical phenomenon, referring to it as the "superiority of speech and wisdom" or the "persuasiveness of wisdom," 29 he sowed the seeds of a persistent Christian ambivalence about the culture of rhetoric. Unwittingly, he anticipated the later Christian distinction between a wisdom of this world (sapientia huius saeculi) versus the genuinely desirable spiritual wisdom (sapientia spiritualis). What is particularly noteworthy is that Paul was not unfamiliar with the traditional philosophical anxiety about sophistic vanities and empty eloquence. He would rather stand accused of being "unskilled in speech" 30 than use the

${ }^{27}$ Iliad 1.201, et al.: हैं $\pi \varepsilon \alpha \pi \tau \varepsilon \rho o ́ \varepsilon v \tau \alpha$.

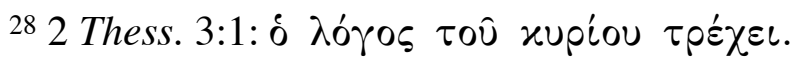

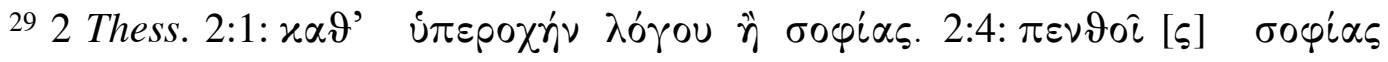

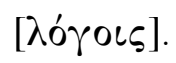

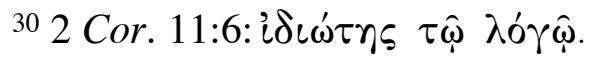


gospel's proclamation to advance his personal gain. Still, his own reservation toward the wisdom of words was based not on the philosophical urge to cleanse language of its magical roots in the dialectical search for truth, but rather on the revolutionary kerygma of the cross of Christ that inverted human values, turning wordly wisdom into foolishness and God's foolishness into genuine wisdom (1 Cor. 1:18-25).

In the first five centuries of the common era the merits and demerits of rhetoric were subject to debate, and the compatibility of rhetoric with the Christian proclamation remained controversial. As is well known, many of the Latin and Greek Fathers were trained in the art of rhetoric, and some were teachers of rhetoric themselves. Tertullian, Cyprian, the three great Cappadocians, John Chrysostom, Jerome, and above all Augustine come to mind. They assimilated rhetoric, but rarely by way of unreflective osmosis. Conscious of the linkage between medium and message, between ancient rhetorical culture and the doctrina Christiana (Christian teaching, not doctrine!), theologians pondered the question of whether rhetoric would compromise the gospel. Origen, a preacher and textual scholar par excellence, had little sympathy for Greek rhetoric as taught in Alexandria and Antioch (Smith 1974:89-90). For others such as Cyprian, a teacher of rhetoric at Carthage, conversion was tantamount to a renunciation of pagan letters altogether (Murphy 1974:49). "What," Tertullian asked provocatively, "has Athens to do with Jerusalem, or the Academy with the church?"31

A matter of great consequence was the elevation of biblical texts to canonical status, creating a mode of privileged authority unknown to GrecoRoman culture. Increasingly, Christian theologians trained as rhetors and rhetoricians had to come to terms with Scripture, be it as source of a new rhetoric or as counterpoint to the old rhetoric. In tracing their Christian identity to the new authority of the Bible, they developed a homiletic mode of discourse, long established in Jewish hermeneutics. Homily, this Christian type of preaching, legitimated the biblical text as principal inspiration and textual guide of the proclamation. The Christian homily was thus a type of rhetoric that was "basically determined by the order of the material in the text, to which may be added material from other texts" (Kennedy 1980:136). As a consequence, memory was often relieved of ecclesiae?

31 De praescr. 7.9: quid ergo Athenis et Hierosolymis? quid academiae et 
problems of invention and arrangement, and a new homiletic rhetoric evolved that was based on and filtered through the medium of the newly privileged text of the Bible.

In spite of the canonization of Scripture that privileged textuality and textually based thematic preaching to a high degree, memory was far from being ejected from the Christian tradition. Augustine himself offered a sustained meditation on the mystery of memory in the tenth and last book of his Confessions. Entirely in keeping with the tradition of ancient rhetoric, he adopted the spatial metaphor of memory, including the deposition of imagines at strategically placed mnemonic loci. He was enraptured with that vast court of memory, this "large and boundless chamber," replete with "numberless secret and inexpressible windings," "the plains and caves and caverns, innumerable and innumerably full of innumerable kinds of things." "The things themselves are not present to my senses; what is present in my memory however are their images," ready to be recalled to sight in the act of remembering. "Great is the power of memory, excessively great, o my God, a large and boundless chamber; whoever sounded the bottom thereof?" he asked exuberantly. ${ }^{32}$ Notably, Augustine's conversion to the Bible and his prodigious chirographic activity did not diminish his enthusiasm and need for the memory tradition of ancient rhetoric.

Augustine belonged to a culture in which quality of thought was intricately related to the powers of remembering: "His memory, trained on classical texts, was phenomenally active. In one sermon, he could move through the whole Bible, from Paul to Genesis and back again, via the Psalms, piling half-verse on half-verse" (Brown 1969:254). And yet, as he probed the deep space of memory, he struck out onto new ground. We note that his encomium in praise of the wonders of memory facilitated remembrance of what he had done, where, and with what feelings. As he lifted these imaged experiences into the full light of his interior vision, he came face to face with his own self. In this way, memory assisted him in the exploration of selfhood, a consciousness made possible by interior

32 Conf. 10.8.15: penetrale amplum et infinitum; 10.8.13: qui secreti atque ineffabiles sinus eius; 10.17.26: campis et antris at cavernis innumerabilibus atque innumerabiliter plenis innumerabilium rerum; 10.15.23: res ipsae non adsunt sensibus meis; in memoria sane mea praesto sunt imagines earum;10.8.15: magna ista vis est memoriae, magna nimis, deus meus, penetrale amplum et infinitum; quis ad fundum eius pervenit? 
visualization. It seemed only sensible to ask if memory, the facilitator of consciousness, also had the power to mediate knowledge of God. Augustine had come to know God, and where else could God abide but in memory? Was God not intelligible as a memorable presence? But as Augustine traversed the vast space of his memory, he had to admit to himself that he could find neither place nor image of God. There was a sense in which his search for God arrived at the cognitive limits of the ancient art of memory. Knowing God, without finding him in his interior recesses, Augustine was compelled to reach beyond memory. "I will pass even beyond this power of mine which is called memory; yea, I will pass beyond it, that I may approach unto Thee, o sweet light. What sayest Thou to me?"33

He again took up the issue of memory in De Trinitate, a psychological study of the trinity unparalleled in patristics. In book eleven he developed the threefold dynamics of the mind that resemble that of the supreme Trinity. Of the many trinitarian structures he uncovered in the mind, the most important one for our purpose was that of memory, vision, and will. The perception of external impressions, internal visualization, and the concentration of the mind, while representing different properties and faculties, converged under the guidance of the will in trinitarian unity: "And so that trinity is produced from memory, from internal vision, and from the will which unites both. And when these three things are combined into one, from that combination itself they are called thought." 34 As far as memory was concerned, Augustine metamorphosed the rhetorical base of mind and memory into the metaphysical realm of trinitarian psychology.

Given the high premium placed on verbal performance and modes of argumentation in Greco-Roman culture, Christianity, which was itself centrally concerned with proclamation, was compelled sooner or later to define its position in relation to classical rhetoric. The task was all the more urgent because Cicero was rapidly advancing to the status of magister eloquentiae and his rhetoric becoming a cultural model for late antiquity and the Middle Ages. In spite of the fact that Christian culture increasingly embraced the Bible and popularized the homiletic style of preaching, the

33 Conf. 10.17.26: transibo et hanc vim meam, quae memoria vocatur, transibo eam, ut pertendam ad te, dulce lumen. Quid dicis mihi?

${ }^{34}$ De Trin. 11.3.36: atque ita fit illa trinitas ex memoria, et interna visione, et quae utrumque copulat voluntate. Quae tria cum in unum coguntur, ab ipso coactu cogitatio dicitur. 
enduring influence of rhetoric demanded that theologians came to terms with its legacy.

No Christian writer in the first five centuries of the common era has addressed this issue more thoughtfully than Augustine. In De Doctrina Christiana, "one of the most original [books Augustine] ever wrote" (Brown 1969:264), he sought to find a rapprochement between the classical institution of oratory and scriptural authority, or, perhaps more accurately, he devised a Christian hermeneutic on its own terms. Few Christians could have been more qualified for the task. From childhood on, rhetoric had been Augustine's single most important cultural influence, and yet his intellectual development took place under the aegis of a literate, increasingly biblical tradition. Indeed, his Confessions have been interpreted as the selfconscious construction of a conversion from an oral, rhetorical to a primarily textual culture (King 1991:150-272).

In book four of this influential treatise De Doctrina, Augustine assigned rhetoric a place in Christian teaching. Eloquence, he stated, could not be rejected out of hand, even though it was intimately associated with paganism. What is more, non-artistic discourse would cripple the Christian proclamation. On a number of substantial points, Augustine holds up as a model of Christian oratory "a certain eloquent man," 35 who is none other than Cicero. For example, Augustine cites with approval Cicero's dictum (De Invent. 1.1.1) concerning the interrelationship of eloquence and wisdom. ${ }^{36}$ In the Christian proclamation, just as in pagan speech, competent rhetoric is not without wisdom, and true wisdom is ineffective without rhetoric (4.5.7). Consistent with Ciceronian principles (Orat. 21.69), Augustine advocates three modes of proclamation, each of which entails its own particular style of speaking. ${ }^{37}$ True eloquence requires that teaching (docere) be done "in a subdued manner" (parva submissa), pleasing (delectare) "in a temperate manner" (modica temperata), and persuading (flectere) "in a grand manner" (magna granditer). And yet, Augustine did not simply plead for a Christianization of conventional Ciceronian rhetoric. De Doctrina, it must be remembered, was a theoretical reflection on the interpretation and teaching of a Christianity that was about

${ }^{35}$ De Doc. Chris. 4.12.27: quidam eloquens.

36 De Doc. Chris. 4.5.7.

37 De Doc.Chris. 4.12.27; 4.17.34. 
to be self-consciously centered in the Bible. What distinguished the Augustinian concept of rhetoric from classical rhetoric was the central role assigned to the Bible. The authoritative status of the Bible was assumed, and so was a biblical rhetoric intrinsic to the central book: "The great virtue of De Doctrina Christiana is that it made it possible for Christians to appreciate and teach eloquence without associating it with paganism" (Kennedy 1980:159). Admittedly, the rhetoric of the Bible may fall short of the oratorical and ornamental features of pagan rhetoric, but in refraining from a more polished language, the Bible communicated what it intended to say.

If absence of sophisticated pompousness was one of the hallmarks of scriptural rhetoric, the presence of obscurity and ambiguity of meaning was another. Augustine was at pains to show how many biblical passages were written in veiled language. The separability of expression from meaning was thereby canonized in Christian hermeneutics. As he saw it, the obscurities of biblical writings were themselves "part of a kind of eloquence" 38 designed to exercise our mental faculties in search of hidden meanings, "for what is sought with difficulty is discovered with more pleasure." ${ }^{39}$ Consequently, the expositor's primary task was neither the demonstration of rhetorical flourishes, nor an appeal to the emotions, but a raising to consciousness of "that which lay hidden." 40 At this point, Augustine's perception of language is a world removed from Gorgias' exuberant endorsement of the magical power of words, and distanced as well from Plato's dialectical discourse of reason. De Doctrina did not expound on the unmediated efficaciousness of spoken words any more than it made a case for dialectical discourse, driven but disciplined by logic. It had more in common with Paul's apprehension at the wisdom of the world, although it did not share in his letters' fundamentally oral disposition toward language. What was new about Augustine's De Doctrina was the privileged status given to a central text. Rhetoric was thereby transformed into a teaching of the biblical texts, which entailed a search for latent meanings. In the end, Augustine's De Doctrina, not unlike his Confessiones, undertook a painfully elaborate and intellectually meandering

${ }^{38}$ De Doc. Chris. 4.6.9: tali eloquentiae miscenda fuerat.

${ }^{39}$ De Doc Chris. 2.6.8: et cum aliqua difficultate quaesita multo gratius inveniri.

${ }^{40}$ De Doc. Chris. 4.11.9: sed ut appareat quod latebat. 
transit from the classical, rhetorical culture of antiquity toward a text-based, Christian hermeneutics.

It would appear that Augustine, never fully persuasive on the matter of biblical rhetoric, adopted a hermeneutic informed by scribal sensitivities. Philosophically, what concerned him most was not the efficaciousness of biblical oratory, but its character of signification. Not content with affirming the allegorical tensiveness in Scripture, he proceeded to elevate the deferring nature of language to a linguistic, theological signs theory. Postulating a distinction between sign (signum) and thing (res), he could at times attribute an astonishingly provisional value to words: "by means of words, therefore, we learn nothing but words." 41 The most that could be said about words was that "they serve merely to suggest that we look for realities." 42 All words, spoken and written, were perceived to be signs that signified the authentic res. Hence, "no one should consider [signs] for what they are but rather for their value as signs which signify something else." 43 Words were mere prompters as it were, and "the realities that were signified were to be esteemed more highly than their signs." 44 In part at least, this theory of signification was born under the pressures of scribal sensibilities. Undoubtedly, signifying deferrals were a commonplace in allegorical, metaphorical, and parabolic speech. Orality and rhetoric had long been familiar with metonymic expansiveness that resonated with the transtextual world, and with figurative language that resisted being taken at face value. However, "Augustine was the first Latin author to call words "signs"" (Swearingen 1991:196). What merits additional attention is his elevation of these processes of linguistic signification into a sign theory. It presumed a lifelong experience with the chirographic status of language as signs, e.g., the embodiment of spoken language in a system of visual symbols. When measured against the ethos of rhetorical efficaciousness, signs were obstacles to the presenting powers of spoken words. In Augustine's case, oral presence was deferred in the interest of a higher goal of unity. The

${ }^{41}$ De Mag. 11.36.5: verbis igitur nisi verba non discimus.

${ }^{42}$ De Mag. 9.36.2: admonent tantum, ut quaeramus res.

${ }^{43}$ De Doc. Christ. 2.1.1: ne quis in eis attendat quod sunt, sed potius quod signa sunt, id est, quod significant.

${ }^{44}$ De Mag. 9.25.1-2: res, quae significantur, pluris quam signa esse pendendas. 
readers of allegorical and otherwise ambiguous scriptural passages were inspired to turn over words in their minds, to move from one hint to another, and from discovery to discovery, each one opening up further depths, and ideally to arrive at the love of God and the vision of God.

In the Western tradition, Augustine's fateful distinction between signifier and signified was a major contributor to a linguistically based bipolarity of metaphysical magnitude. It was replayed in a myriad of ways, pitting exteriority against interiority, the letter against the Spirit, the sensible against the intelligible, the written text against the transcendental Logos, temporality against eternity, and so forth. In the end, it may be said that Augustine's assimilation of rhetoric to scribality created a kind of "metarhetoric" (Murphy 1974:287), or perhaps more precisely, a Christian hermeneutics of communication at the heart of which lay the metaphysical nature of language. In this fashion, it made an indelible impact on medieval concepts of language, buttressing the whole medieval world of analogies and correspondences.

A Christian codex dated prior to 1000 C.E. depicts Pope Gregory the Great (540-604 C.E.) as interpreter of Scripture. The miniature carries the title: Pope Gregory I inspired by the Holy Spirit (Gumbrecht/Pfeiffer 1993: 726-29). His left hand rests on an open book that is placed on a lectern. Undoubtedly, this book represents the holy Bible. In his right hand Gregory holds another book that is closed. Decorated with a golden cover, it appears to be a copy of the Bible. A white dove, a symbolic representation of the Holy Spirit, sits on the right shoulder of the Pope. The dove's beak is wide open and placed near the ear of Gregory: the Holy Spirit inspires the Pope. Gregory's gaze is directed neither toward the viewer nor toward the books. His is a posture of auditory concentration. He is listening to the words of the dove whispered into his ear. Behind Gregory, separated by a curtain, sits a scribe. In his right hand he holds a stilus, a sharp slate-pencil, and in his left hand a writing tablet. With the stilus he points toward the dove, source of inspiration, and with his writing tablet he gestures toward the Pope, possessor and mediator of Scripture. Presumably, the scribe receives the Pope's dictation that had been transmitted to him through the mediation of the Spirit. 


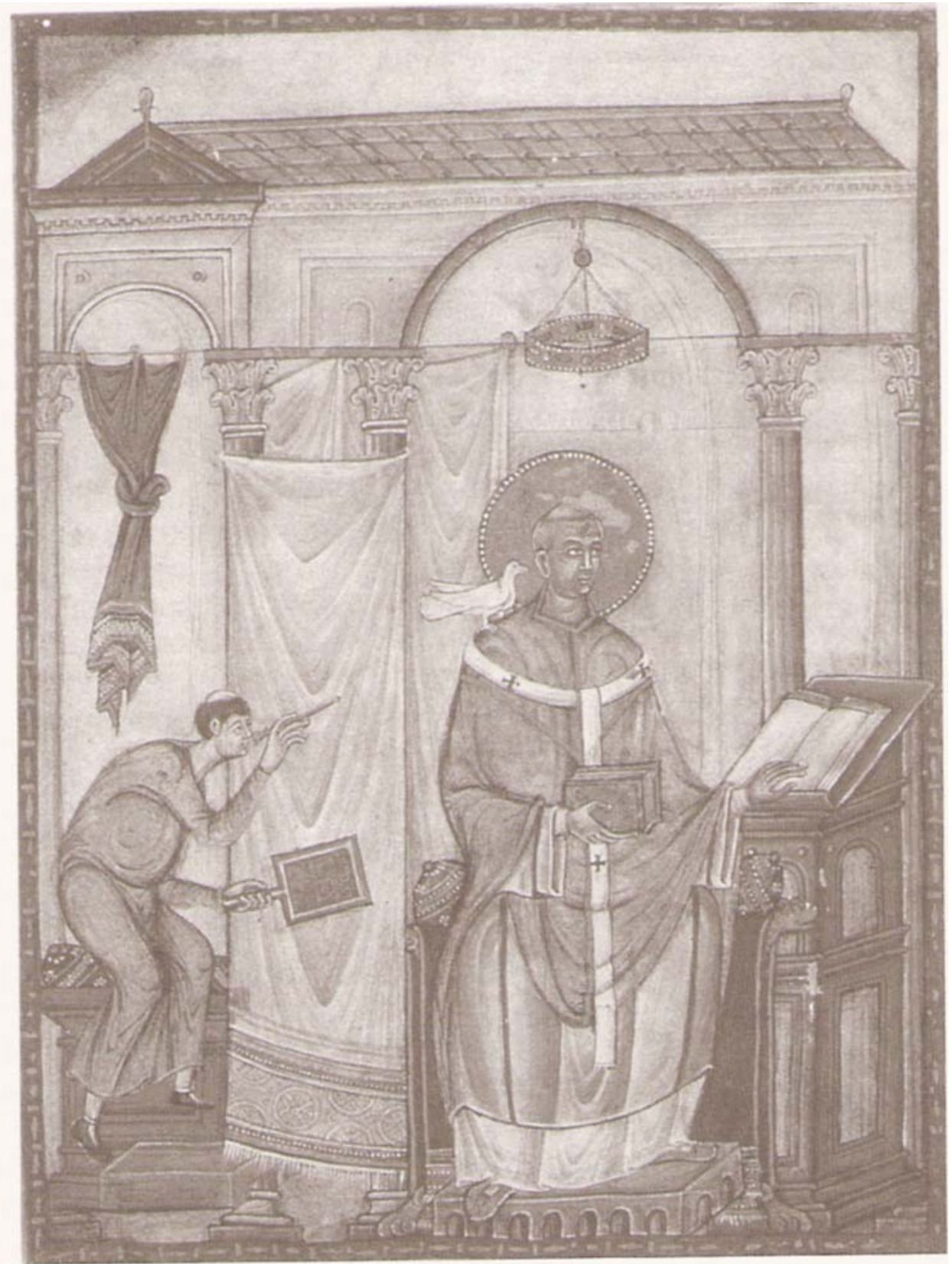

Tenth-century manuscript illumination by the Master of the Registrum Gregorii, Trier 983/84. Stadtbibliothek Trier, Ms. 171a. (The author acknowledges his gratitude to the Stadtbibliothek Trier for granting permission to republish the illustration of Pope Gregory I.) 
The miniature may serve as a central metaphor for both the grand simplicity and the notable complexity of medieval linguistic and religious culture. It locates the Pope, assuredly, at center stage: he is the pre-eminent authority and chief interpreter of the Holy Book. Apparently, the meaning of the Bible is not self-evident. As sacred text it partakes of secrecy. For secrecy "is a way of figuring Scripture as a book of revelation which nevertheless ... withholds a good portion of itself" (Bruns 1982:18). Indeed, secrecy is an indispensable category of sacred writings (17-43). Thus, although widely understood to be the unified and unifying Word of God, the Bible was experienced as a text written in veiled language. Its authority was firmly established, but its written status raised a host of interpretive questions. There is a sense, therefore, in which the miniature dramatizes the intricacies of a hermeneutical scenario surrounding the sacred text.

Encoded in the miniature were differences that called for hermeneutical mediation. The Spirit, represented by the dove and source of auditory inspiration, was once removed from the Pope, twice removed from the Bibles, and thrice removed from the scribe behind the curtain. Moreover, the open book of revelation was placed side by side with the closed book of revelation, and both Bibles were separated by a curtain from the scribe who was about to commit the Pope's dictation to writing. Thus medieval Christian culture, centered on the Pope, the Bible, the Spirit, and the scribe, has set into motion a process of triple mediation. Assisted by the agency of the Spirit, the Pope was enabled to read and to open the closed book of the Bible, and to mediate his reading to the scribe who in turn transposed the dictation into writing, thus producing another text. The very text-centeredness of the Bible is obvious, and yet its chirographic status is innocent of the modern perception of intertextuality that imagines a devocalized environment in which texts relate impersonally to other texts. The miniature clearly conveys the impression that the connective tissue that mediated textual meaning, the Spirit's whisperings and the Pope's dictation, was oral in kind.

Partially influenced by the growing dominance of the Bible, and fostered by the scribal traditions of monasticism and scholasticism, an increasing output of manuscripts was generated that lay at the basis of medieval cultural and intellectual life. Still, if one wishes to comprehend the Middle Ages from the perspective of communications changes, one must imagine trends of the type of la longue durée. The period roughly from the 
fall of Rome to the invention of printing saw a general shift from oral performance to chirographic control of writing space. Manuscripts increasingly became important tools of civilized life, and from the eleventh century onward an ever-growing scribal culture shaped the processes of learning. One must, however, guard against simplistic divides of orality versus textuality, against anachronistic notions of medieval textuality, and against facile premises concerning links between manuscript technology and the restructuring of consciousness. It bears repeating that this picture of the textualization of the medieval world is correct only on the macro-level of history.

Medieval scribality was a craft that required mastery of a variety of tools and skills. The production of manuscripts was hard labor, "a seasonal activity like football" (Troll 1990:118), but rarely of a gratifying intellectual nature. In so far as scribes were copyists, they worked in the interest of preservation and transmission of knowledge; when they took dictation, they served as catalysts of orally dictated compositions. But whether they copied or took dictation, scribes were craftsmen, not personalities eager to think for themselves or to advance knowledge. Whether medieval scribal craftsmen were engaged in monastic discipline or conscripted into the paid service of rulers and administrators, theirs was always hard manual labor, indeed drudgery, which did not advance their libido sciendi any more than it stimulated their urge for self-expression and individuation.

More importantly, the effects of manuscript technology were not directly translatable into literacy. We do well to keep scribal textuality distinct from literacy. Some of the most exquisite medieval scribal productions, the illuminated Bibles, were primarily sacred artifacts, objects of ritual celebration, rather than direct sources of intellection. As a craft revolution, scribality enhanced the availability and status of texts. But the literate revolution, that is, the formation of a broadly based and informed readership, did not get underway until the sixteenth century when print technology revolutionized communications processes. In medieval culture, not only did literacy remain the privilege of few, but reading and writing did not inevitably connect to form a literate mentality. Reading was widely practiced as an oral activity (Balogh 1926, Saenger 1982, Achtemeier 1990). To be sure, aids to visual apperception slowly increased. Punctuation and word and chapter divisions, initially introduced in support of oral reading, imposed a visual code upon manuscripts, a process that 
gradually encouraged silent copying and silent reading. Still, far into the high Middle Ages "reading was regarded as an active energetic exercise, requiring good health, and not as a passive sedentary pastime" (Saenger 1982:382; cf. 377-82). The recipients of texts were often listeners who did not necessarily know how to write, while scribal copyists were frequently unable to comprehend what they wrote. "Reading" was linked with the dictation and recitation of texts more than with private reflection. What constituted "literate" intellectualism was thus not necessarily the combined skills of reading and writing, but rather a high degree of audiovisual apperception and memorial practices (Carruthers 1990).

Undoubtedly, the high culture of medieval learning, which excelled in formulating intricate philosophical, religious, and linguistic theses with signal keenness of intellect, was the beneficiary of a developing chirographic activity. Once ideas and experiences were enshrined in writing, they began to assume a semblance of stability, irrespective of their continued oral functioning. Once knowledge was detached from the oral traditional biosphere, it was disposed toward depersonalization, and hence subject to reflection and analysis. Relentless scribal labors extended the texual base that slowly but inevitably enhanced the possibilities of comparative and critical thought. In this high intellectual culture, reflections on language, cognition, mind, and memory were increasingly shaped by a working relationship with texts.

There was an additional feature that uniquely assisted medieval coherence and consciousness: the use of the Latin language. Medieval intellectualization owes as much, if not more, to the use of Latin as to scribal productivity. ${ }^{45}$ For at least a thousand years, roughly from the sixth to the sixteenth century, the Western Middle Ages was under the governing influence of Latin. Litterati were primarily those canonists, diplomats, administrators, and theologians who had mastered Latin-which may or may not have included the ability to read and write. ${ }^{46}$ Latin became a standard of medieval high culture and the vehicle of theological, philosophical achievements. Coleman's observation that in certain monastic circles the assiduous study of grammar "was meant to teach a way to reach heaven through latinity" (1992:145) could well be extended to the

${ }^{45}$ Ong 1967:76-79, 250-52.

${ }^{46}$ Stock 1990:26, Troll 1990:112. 
aspirations of many clerical litterati: Latin was perceived to be the linguistic medium that aided in the ascent to heaven. But with the rise of ethnic, national identities, Latin either followed the concomitant upsurge in vernaculars and developed into the Romance tongues, or it turned into learned Latin, a "chirographically controlled glacier" (Ong 1967:78) that had little or no broad-based social marketability. But it was precisely learned Latin's abstraction from oral life that increased its value as an ideal instrument for the academic scholarship of a culture elite. High medieval intellectual culture was thus the result not only of a rapidly increasing chirographic productivity, but of a distinctly Latin type of literacy that had removed itself from the oral lifeworld.

Even though manuscripts eventually came to function as articifial memory bases in their own right, medieval scribality and latinity neither displaced nor vacated memory. Quite the opposite. For centuries the growing body of texts only intensified and complicated demands made on memory: "Medieval culture remained profoundly memorial in nature, despite the increased use and availability of books . . ." (Carruthers 1990:156). Not only was there more and more material that had to be processed, more and more authoritative voices that had to be registered and reconciled, but changing cultural circumstances enlisted memory into new services. As far as preoccupation with memory was concerned, medieval Christian intellectualism in no way lagged behind antiquity, although memory was often exiled from its natural home in rhetoric and assimilated to new religious and epistemological tasks (cf. Coleman 1992).

The French Cistercian reformer Bernard of Clairvaux, who represented medieval monasticism at its height, contributed to the conversion of memory from the theory of rhetoric's esteemed treasure-house of eloquence to a symbol of religious reconstruction. Steeped in the monastic experience of hard labor, prayer, and silence, he saw little meaning in memory as a depository of precious icons and loci that negotiated cognition and consciousness. His religious experience taught him that memory was a house that was "contaminated with intolerable filth." ${ }_{47}$ Into it, "as if into some cesspit runs all abomination and uncleanness." 48 "Why should I not grieve for the stomach of my memory,"

${ }^{47}$ De Con. 4.8: intolerabili fetore contaminat.

${ }^{48}$ De Con. 3.4: velut in sentinam aliquam, tota decurrit abominatio, et immunditia tota defluxit. 
he exclaimed, "which is congested with such foulness?"49 He advised his audience to "close the windows, lock the doors, block up the openings carefully" 50 through which so much filth has infiltrated and clogged up memory. While Bernard was careful to state that memory itself should be left intact, he advised his hearers "to purify memory and pump out the cesspit." ${ }_{1}$ However brief the enticements of sensual experiences, "the memory is left with a bitter impression, and dirty footprints remain." 52 These, too, should not be erased altogether, but retrained and enlisted in the service of smelling, inhaling, tasting, seeing, and hearing the delights of charity, hope, and spiritual pleasures. Memory thus reconstructed-purged and equipped with a converted sensory base-was able to facilitate the believers' gradual attainment of spiritual purity. Steeped in monastic discipline, Bernard turned memory, rhetoric's treasure-house of knowledge and Augustine's instrument of self-knowledge, into a vehicle of religious conversion.

Scholasticism, one of the supreme philosophical and theological achievements of the Middle Ages, registered in different ways the cultural revolution marked by scribal productivity and latinity. A hallmark of scholasticism's intellectual project was the compilation and juxtaposition of biblical, patristic, and philosophical authorities. The need for collecting seemingly discordant authorities is a procedure utterly foreign to us. The project was founded on the fundamental premise of the two distinct, but reconcilable, sources of truth, theology, and philosophy. More is at stake here than the oral penchant for quoting authorities. The drive toward the collection and juxtaposition of authorial voices was in part at least attributable to the textualization of medieval learned culture. It was thrust upon scholastic theologians by the steady growth and growing diversity of Latin texts. The translation of Aristotle from Greek and Arabic into Latin from the tenth through the twelfth centuries had a particular bearing on this development. Here was an activity that made available systems of thought

${ }^{49}$ De Con. 3.4: quidni doleam ventrem memoriae, ubi tanta congesta est putredo?

${ }^{50}$ De Con. 4.8: claude fenestras, obsera aditus, foramina obstrue diligenter.

${ }^{51}$ De Con. 15.28: purganda scilicet memoria et exhaurienda sentina.

52 De Con. 3.4: memoria quaedam impressit signa memoriae, sed vestigia faeda reliquit. 
(Aristotle, Avicenna, Averroes) that were not only independent of theology, but placed a high premium on reason and rational reflection (Coplestone 1985:II, 205-11). The compilation of discordances, the passion for weighing and comparing different opinions, the contraposition of authorities, and the desire to seek clarification amidst authorial dissonance were all features traceable to growing intellectual diversity based on a rapid enlargement of the textual database. This is precisely what the scholastic theologian Peter Abailard conceded in the prologue to Sic et Non, a collection of seemingly contradictory authoritative statements on 150 theological issues. What necessitated his labors, he wrote, was "the very vastness of verbal materials," which "appeared to be not only in themselves different, but truly also contradictory." 53

While driven by the conditions of a textual revolution, the scholastic method of organizing thought remained indebted to a form of dialectic. Adopting a pattern of threefold schematization, issues were isolated and discussed by way of explication of objections, argumentation of resolution, and refutation of objections (Grabman 1909-11:I, 28-54). Rather than proceeding along the lines of a sequential, discursive logic, the scholastic art of structuring thought still operated in the tradition of a disputatious dialectic. But the scholastic dialectic differed from the Platonic dialectic, which had intended to keep thought alive in the flow of living discourse. The dialectic of St. Thomas' Summa Theologiae, for example, was characterized by a nonemotional, stylized quality of thought and a severe asceticism of language. His intellectualism moved in the rarified world of intensely abstract thought. Both in its organization of thought and in the delivery of ideas, it presented itself as a paragon of supreme rationalization. In its passion for rational penetration, the Summa practiced argumentation in a highly formalized dialectic. It is generally acknowledged that the strategies of scholastic dialectic originated in the medieval system of academic learning (Grabman 1909-11:I, 31-32; Coplestone 1985:II, 21415). It was in university settings that teachers trained students by prompting them to raise objections to propositions, by directing the processes of argumentation, and by formulating final resolutions. This was the cultural context, in which medieval philosophers from the tenth to the fifteenth centuries shaped the tradition of academic dialectic into an

53 Sic et Non, I, 1-2: . . .tanta verborum multitudine. . . non solum ab invicem diversa verum etiam invicem adversa videantur. 
instrument of high-powered precision, composing in a Latin that was neither that of the ancients nor that of the Fathers, but a Latin of a distinctly scholastic diction. However, it is typical of the harmonizing disposition of Thomas' Summa that the authorities were secured in tradition more than seriously challenged, that more often than not the objections raised were of a perfunctory rather than a substantive kind, and that the resolutions were anticipated in advance of the argumentation. This is but another way of saying that Thomistic dialectic, this highly formalized academic ritual that was passionately devoted to logic, was at the same time constrained by rhetorical conventions (Kinneavy 1987:90-94). Viewed from this perspective, the scholastic method of Thomistic dialectic, anchored in logic yet beholden to rhetorical premises, manifested the old and unresolved conflict between rhetoric and logic.

The question of what memory was and how it collaborated with the mind had to be assimilated to the new intellectual system of scholasticism. In substance, Thomas reiterated the ancient rhetorical theory of the mnemonic imagines and loci, adding the advice that one must cleave with affection to the things to be remembered in order "to keep the shape of images intact." ${ }_{54}$ Thomas fully shared the Aristotelian premise that "all our cognition takes its rise from sense perception." ${ }_{55}$ In his commentary on Aristotle's De Memoria et Reminiscentia he returned again and again to the commonplace proposition that "man cannot understand without image." ${ }_{56}$ In part at least, human knowing was conceived on the analogy of interior visualization; it originated in phantasmata or corporeal images that were situated in memory. To be sure, parts of memory had the faculty of entertaining thoughts and opinions, but in principle no human thinking could take place without some kind of imaging. Additionally, memory's imaginary perception was always of particulars; it had no grasp of universals. Owing to the scholastic axiom that "it is natural to man that he should come to the intelligible things," e.g. the universals, "by way of the

54 Summa, vol. 36, quaestio. 49: conservat integras simulacrorum figuras.

55 Summa I, 1, quaestio 1: omnis nostra cognitio a sensu initium habet.

${ }^{56}$ Liber I, lectio 2: non possit homo sine phantasmate intelligere. 
sensible things," e.g. the particulars, ${ }^{57}$ memory and its menu of icons served as the indispensable base for all our cognitive processes. In reflection on and abstraction from the particularity of sense images, intellectual cognition came to know what was truly worth knowing: the divine universals. With Thomism, memory was thoroughly integrated into the medieval system of knowledge and faith. But it is worth noting that in the new scheme of things, memory functioned no longer in its classic oral sense as a treasurehouse of eloquence, but metaphysically, as a mediator of universals and facilitator of the knowledge of God.

There was yet another, more obvious sense, in which Thomas strove to disengage memory from its traditional base in rhetoric. Not content with assigning memory to the metaphysics of knowing, he also reassigned it to ethics. Memory, originally the mother of the nine Muses, had become one of eight components of prudence, the governing queen of all moral virtues. Since prudence had made it her business to secure knowledge about the future based on past or present experiences, ${ }^{58}$ and memory sought to store knowledge about the past, ${ }^{59}$ prudence depended on memory. Hence, prudence and memory were expected to cooperate in the interest of discerning matters in advance so as to facilitate the right course of action. Although thoroughly familiar with the ancient and medieval disciplines of memory, Thomas refrained from commending memory as rhetoric's treasure-house of eloquence. This fact will not have come about entirely without the pressures of scribality. At a time when handwritten materials came increasingly into use, memory began to lose its ancient rhetorical rationale, and as it forfeited its base in rhetoric, Thomas recommended it as a helpmate of prudence based on considerations of practical reason. ${ }^{60}$

We shall conclude with a model of cognition that manifested both the height and incipient demise of scholasticism. William of Ockham, whose thought is frequently viewed in connection with the nominalism of the fourteenth and fifteenth centuries, remains "to this day the most

57 Summa I, 1, quaestio. 1: est autem naturale homini ut per sensibilia ad intelligibilia veniat.

58 Summa, vol. 36, quaestio. 47.

${ }^{59}$ Quaestio. 48.

${ }^{60}$ Quaestio. 47: quod est finis practicae rationis. 
controversial thinker of medieval intellectual history" (Klein 1960:1556). Best known for his anti-realist position in the controversy over the universals, the Franciscan friar rethought epistemology and helped clear the way for what came to be known as the via moderna. He was "perhaps the greatest logician of the Middle Ages" (Ockham-Boehner 1990:xviii), whose logical brilliance, verbalized in stunningly abstract Latin, was nourished by close rapport with a flourishing scribality. At the same time, Ockham's philosophy exhibited a distinct reserve toward rhetoric, dialectic, and imagination.

It was a deeply held conviction of medieval realism that language, memory, and sense perception collaborated in the higher interest of universal knowledge. In fact, divine universals, eternally true realities, were the appropriate objective of the mind's aspirations. More than that, to universals was attributed the status of truly existent metaphysical realities. The crux of Ockham's controversial work was that it problematized the reality corresponding to universals outside the mind: "a universal is not a substance existing outside the mind in individuals and really distinct from them." 61 He refused to admit that there was anything in the experienced world that corresponded to the universality of a concept. Universality was a function of the actus intellegendi (8), a mental construct, or simply the manner in which the mind achieved sufficiently generalized abstractive cognition.

As a logician, Ockham was well aware that the requirements for demonstrating the being of God were exceedingly difficult to fulfil. Nonetheless, in an argument of tortured logic he undertook to prove the proposition that God existed, ${ }^{62}$ while conceding all the same that God's existence "cannot be known from propositions by themselves, since in every argument something doubtful or derived from faith will be assumed." 63 The unity of God, on the other hand, was not subject to logical

61 Epis. Pro. 6: universale non sit aliqua substantia extra animam existens in individuis distincta realiter ab eis.

62 Proof. Ex. 6: sciendum tamen, quod potest demonstrari Deum esse.

${ }^{63}$ Ibid.: nec potest probari ex per se notis, quia in omni ratione accipietur aliquod dubium vel creditum. 
demonstration. ${ }^{64}$ It could only be assumed in faith. ${ }^{65}$ On the whole, however, Ockham was more adept at demonstrating what was not demonstrable about God than in confirming his verifiable attributes.

If Ockham's preoccupation as a philosopher was to purge Christian epistemology of the metaphysics of essences, it was not because he was prompted by agnostic impulses. Nothing could be further from the truth. His philosophical intention was to immunize divine freedom and omnipotence from what he regarded as human essentialist interventions. There was no inherent necessity for anything in this world to be just as it was. So far as God was concerned, things might be different. If, therefore, the world was contingent, as Ockham thought it was, it was contingent by divine choice, and hence knowable only by its contingency.

Given this worldly contingency, Ockham held to an epistemology that presumed an autonomy of mind, memory, and cognition. Priority was assigned to intuitive cognition, and immediate apprehension of the particulars by intuitive cognition preceded all other modes of knowing. In Ockham's words, "a cognition which is simple, proper to a singular thing, and the first to be acquired, is an intuitive cognition." 66 Only in secondorder acts of thought, the so-called abstractive cognition (cognitio abstractiva), could things perceived lead to the formation of images and propositions. But even these second-order mental acts relied only partially on images. Concepts and images, moreover, neither represented metaphysical essences nor did they invite cognitive ascent toward divine universals. They were merely mental substitutions for the particulars.

Ockham's skepticism with regard to philosophical realism moved the particular, the experiential, and the contingent to the center of inquiry. Consequently, his model of language and thought focused with unprecedented force upon the status and quality of distinctiveness, including the particularity of texts. Scripture, indeed all texts, was assumed to be operating according to something akin to an intrinsic linguistic economy, and the operations of the mind-everybody's mind - were such that they could access the internal textual logic via the cognitio intuitiva. Gorgias'

${ }^{64}$ Ibid.: unitas Dei non potest evidenter probari.

65 Ibid.: sed hoc fide tantum tenemus.

66 Epis. Pro. 3: cognitio simplex, propria singulari et prima tali primate est cognitio intuitiva. 
oral theory of language, which had manifestly postulated persuasive powers over the soul, was a thing of the past. One looks in vain, moreover, for a special commitment to rhetoric. As Ockham came to view things, language was not primarily meant to arouse emotions. Furthermore, the status of memory was once again modified. Divorced from its rhetorical, metaphysical, and ethical obligations, memory became a part of abstractive cognition and subordinated to intuitive cognition. No longer the treasurehouse of eloquence, or the metaphysical abode of trinitarian psychology, or a vehicle of conversion, memory came to play the role of an almost Proustian remembering of things past.

Most importantly, the Augustinian sign theory, which had canonized the metaphysical nature of language, was not replicated in Ockham's thought. It was not that he discarded the signs character of language, but he reintegrated it into his nonmetaphysical notion of cognition. The word as sign, he wrote, "does not make us know something for the first time . . , it only makes us know something actually which we already know habitually."67 Nowhere does one encounter in Ockham the Augustinian correspondence between signum and res. There was no discernible correspondence between the linguistic signs and the metaphysical realities. The signs character of language had become an intrinsically linguistic phenomenon transposed into intramental processes. More than that, Ockham could in a spirit almost akin to postmodernism state that "a spoken and written term does not signify anything except by free convention." 68 In postmodern linguistic terms, the relation between the signifier and the signified was an arbitrary one.

A principal feature of Ockham's model of mind and language was a mode of thought that ran counter to the universalizing thrust of Platonic, Augustinian, and scholastic philosophy. Ockham approached epistemology and theology from the side of the particular - "a change of outlook almost as epoch-making as the Copernican revolution in astronomy" (OckhamBoehner 1990:xxvii). In the history of humanistic thought, it was a revolution less popularly known but no less significant than the Platonic revolt against the poetic encyclopedia of ancient Greece. A certain

${ }^{67}$ Log. Pro. 1: non faciat mentem venire in primam eius . . ., sed in actualem post habitualem eiusdem.

68 Ibid.: terminus . . prolatus vel scriptus nihil significat nisi secundum voluntariam institutionem. 
underpinning, although by no means the single cause, of both Plato's universalist and Ockham's particularist turn was provided by the technology of chirography, which in Ockham's case was reinforced by a high-intensity Latin. When Plato aspired to the essence of things abstracted from the Homeric poetic tradition, and liberated from oral, tribal pluralism, he was aided and abetted by the alphabetic revolution in ancient Greece. In Ockham's case, it was his reliance on the inner resources of a chirographic tradition, matured to a highly stylized Latin, that fostered the mental and psychological distancing from the metaphysical superstructure. Paradoxically, it took Latin's withdrawal from life, and a penetrating reflection on the fundamental problems of logic, in order to come to the realization that the essence was in the things themselves.

That Ockham was in fact a privileged and eager beneficiary of scribal culture is well established. From the eleventh century on, manuscripts had increasingly become the working material for the cultural elite: "His whole scholarly life until 1330 was spent in the greatest of European universities, his circle the most 'bookish' of the time" (Carruthers 1990:158). The year 1330 marked a watershed in his life. In that year he moved, in compliance with a papal ruling, to a Franciscan convent $[\mathrm{sic}]$ in Munich where he lived, cut off from all major University libraries, until the end of his life in 1349. Whereas the Munich period saw the publication of distinctly political, ecclesiastical writings, virtually all of his philosophical and theological books were written prior to 1330 . How important a role written materials had played in the formulation of his epistemology is underscored by the bitter complaints he issued from Munich about the unavailability of books (Carruthers 1990:89).

Let us return to the miniature of Gregory the Great that had portrayed the authorities of the Pope, the Bible, the Spirit, and the scribe in a dramatization of medieval hermeneutics. Ockham revised this drama by shifting the balance of authorities. The most consequential implication of Ockham's theology was a decentering of the Pope in the interest of a sharpening of focus upon the Bible, and the implementation of a cognitio intuitiva, an immediate cognitive apprehension of Scripture. The textcenteredness, recognizable to a degree already in the miniature of Gregory the Great, had thereby acquired a sense of authorial objectivity. With a force unknown to previous thinkers, Ockham moved the textual authority of Scripture and its individual interpreters to center stage, anticipating events that would not come to historical fruition (and explosion) for another two 
centuries. For the focus upon scriptural authority and the attribution of interpretive powers to individual human cognition prepared the way for a potentially conflictual relation between the authorities of the Pope and the Bible.

In paying tribute to Milman Parry and Albert Lord, this lecture has suggested degrees of connectedness between oral and chirographic incarnations of the word and the structuring of human thought. Our premise is furthest removed from the notion that language and different linguistic embodiments are comprehensible as neutral carriers of ideational freight. In the spirit of Parry and Lord, we have postulated that modes of communication were themselves potential embodiments of cognition and shapers of consciousness.

Glancing over the long haul of ancient and medieval history, we have made a set of observations concerning shifting roles of language, memory, and sense perception. Speech as divine madness was viewed as the product of a linguistic culture that was dominated by an orality largely untamed by the powers of chirography. Rhetoric, taking advantage of the technology of writing, made speech conscious of itself and also subservient to civic life. Few experiences enhanced Western text-consciousness more deeply than the canonical centering of the Bible. It helped reshape ancient rhetoric into Jewish and Christian modes of homiletics, and unleashed a seemingly unending flow of midrashic rewritings of the privileged biblical texts.

Memory, the wellspring of civilized life, was a continuing theme in ancient and medieval culture that was in fundamental ways a memorial more than a documentary culture, notwithstanding the increasing production and availability of books. But the praxis of memory changed as different media circumstances exempted it from strictly rhetorical obligations and enlisted it into the service of ethical, metaphysical, and historical remembrance.

The fundamentally oral, rhetorical understanding of the cognitive value of the sensorium was widely shared by ancient and medieval thinkers. Plato's striving after pure, disembodied thought never found credence with a majority of thinkers. Elsewhere in ancient and medieval thought, cognition was perceived to be sensory cognition. But a growing manuscript 
culture, and the possibilities it raised for detached thought, left its impact on the role of the sensorium as well. Among the cultural elite, the developing processes of medieval scribality went hand in glove with the privileging of Latin that, shaped into a finely tuned instrument for rational discourse, increasingly forfeited its marketability in a world of ethnic and vernacular turmoil.

Scholasticism's hierarchical thematization of the sensibilia versus the intelligibilia acknowledged both the foundational role of the former and the superiority of the latter. What William of Ockham set into motion was a reversal of Thomistic scholasticism, for which universals alone had been the proper object of knowledge. If what mattered were not the universals but the particulars, attention was refocused upon the philosophically conventional, the culturally distinctive, and the linguistically contextual. Thus in a time of growing literacy, individual believers found themselves confronted with the internal logic of the biblical texts. The Bible as central grammatological authority was thereby reinforced in ways unheard of before. But if it was admitted that the biblical texts operated under logical laws that could be intuited by the minds of individual interpreters, then the Pope's authority as pre-eminent interpreter of the Bible had implicitly been called into question. A whole set of far-reaching historical and theological implications came into play, relentlessly text-centered implications, that reached their culmination in the sixteenth century. For in so far as the Reformation came to elevate the sensus literalis to the exclusion of all other senses, and to embrace the principle of sola scriptura vis-à-vis papal authority, and to adopt the notion of scriptura sui interpres (Scripture is its own interpreter), it fulfilled the legacy of the via moderna, a legacy principally set into motion by Ockham and his successors.

Rice University

\section{References}

Ancient and Medieval Works

Abailard (ca. 1079-1142) Peter Abailard. Sic et Non. Ed. by Blanche B. Boyer and Richard McKeon. Fascicles 1-4. Chicago: University of Chicago Press, 1976-77. 
Ad Herennium (ca. 86-82 B.C.E.)

Aristotle (384-322 B.C.E.)

Augustine (ca. 389)

Augustine (ca. 400)

Augustine (ca. 399-419)

Augustine

Augustine (ca. 396-427)

Augustine

Bernard (1090-1153)

Bernard

Cicero (106-43 B.C.E.)

Cicero (106-43 B.C.E.)
Anonymous. Trans. by H. Caplan. Loeb Classical Library. Cambridge, MA: Harvard University Press, 1954.

Aristotle. "On Memory and Recollection." In On the Soul, Parva Naturalia, On Breath. Trans. by W.S. Hett. Loeb Classical Library. Cambridge, MA: Harvard University Press, 1936. pp. 283-307.

Aurelius Augustinus. De Magistro. Corpus Christianorum, Series Latina. Pars II, 2. Turnholti: Typographi Brepols Editores Pontifici, 1970.

- S. Aureli Augustini Confessionum. Ed. by Martin Skutella. Stuttgart: Teubner, 1981.

De Trinitate. Cols. 819-1098 in J.-P. Migne, Patrologia Latina, 42. 1861.

. On The Trinity. Trans. by Arthur West Haddan.

The Works of Aurelius Augustine, Bishop of Hippo. Ed. by Marcus Dods, vol. 2. Edinburgh: T. \& T. Clark, 1873.

. De Doctrina Christiana. Cols. 15-122 in J.-P. Migne, Patrologia Latina, 34. 1861.

. On Christian Doctrine (De Doctrina Christiana). Trans. by D.W. Robertson. The Library of Liberal Arts. New York and London: Macmillan, 1958.

Bernard of Clairvaux. Sermo de Conversione. Cols. 83356 in J.-P. Migne, Patrologia Latina, 182. 1862.

Selected Works. Trans. by G. R. Evans. New York-Mahwah: Paulist Press, 1987.

Marcus Tullius Cicero. De Oratore. Books I, II. Trans. by E.W. Suttton. Cambridge, MA: Harvard University Press, 1942.

De inventione. De Optimo Genere, Oratorum Topica. Trans. by H. M. Hubbell. Loeb Classical Library. Cambridge, MA: Harvard University Press, 1949. 
Gorgias (ca. 483-375 B.C.E.) Gorgias von Leontinoi. Reden, Fragmente und Testimonien. Ed. by Thomas Buchheim. Hamburg: Felix Meiner, 1989.

Homer (8th century B.C.E.) Homer. The Iliad of Homer. Trans. by Richmond Lattimore. Chicago: University of Chicago Press, 1976.

Homer The Iliad. Ed. by Walter Leaf. 2nd ed. Books IXII. Amsterdam: Adolf M. Hakkert, 1960.

Ockham (ca. 1285-1349) William of Ockham. Philosophical Writings. Trans. with intro. and notes by Philotheus Boehner. Indianapolis and Cambridge: Hackett Publishing, 1990.

Plato (427-347 B.C.E.) Plato. The Collected Dialogues of Plato. Ed. by Edith Hamilton and Huntington Cairns. Bollingen Series, 71. Princeton: Princeton University Press, 1961.

Plato Platonis Dialogi. Ed. by Karl Friderich Hermann. vols. 1-4. 1859-63.

Quintilian (ca. 40-95)

Quintilian. The Institutio Oratoria. Loeb Classical Library, vol. 4. Trans. by H. E. Butler. London: William Heineman and New York: G.P. Putnam's, 1922.

Tertullian (ca. 160-225)

Tertullian. "De Praescriptione Haereticorum." In Corpus Christianorum Series Latina. Tertulliani Opera, Pars I. Turnholti: Typographi Brepols Editores Pontifici, 1954.

Thomas Aquinas, St. (1225?-74)

Thomas Aquinas, St.

Thomas Aquinas, St.
Thomas Aquinas. De Memoria et Reminiscentia. In Opera Omnia. Ed. by Stanislai Eduardi Fretté. vol. 24. Paris: Ludovicum Vivès, 1875. . Summa Theologiae. Vol. 1, Christian Theology. Text, trans., and intro. by Thomas Gilby. Cambridge: Blackfriars and New York: McGraw-Hill; London: Eyre and Spottiswoode, 1963. Summa Theologiae. Vol. 36, Prudence. Text, trans., and intro. by Thomas Gilby. Cambridge: Blackfriars and New York: McGraw-Hill; London: Eyre \& Spottiswoode, 1974. 
Contemporary Works

Achtemeier 1990

Balogh 1926

Betz 1979

Brown 1969

Bruns 1982

Bultmann 1910

Carruthers 1990

Coleman 1992

Coplestone 1985

De Romilly 1975

Foley 1990
Paul J. Achtemeier. "Omne Verbum Sonat: The New Testament and the Oral Environment of Late Western Antiquity." Journal of Biblical Literature, 109:3-27.

Josef Balogh. "Voces Paginarum." Philologus, 82:84109, 202-40.

Hans Dieter Betz. Galatians. A Commentary on Paul's Letter to the Churches in Galatia. Hermeneia. Philadelphia: Fortress Press.

Peter Brown. Augustine of Hippo. Berkeley: University of California Press.

Gerald L. Bruns. Inventions: Writing, Textuality, and Understanding in Literary History. New Haven: Yale University Press.

Der Stil der paulinischen Predigt und die kynisch-stoische Diatribe. Forschungen zur Religion und Literatur des Alten und Neuen Testaments, 13. Göttingen: Vandenhoeck \& Ruprecht. Rpt. 1984.

Mary Carruthers. The Book of Memory: A Study of Memory in Medieval Culture. Cambridge: Cambridge University Press.

Janet Coleman. Ancient and Medieval Memories: Studies in the Reconstruction of the Past. Cambridge: Cambridge University Press.

Frederick Coplestone. A History of Philosophy. Garden City, NY: Image Books.

Jacqueline de Romilly. Magic and Rhetoric in Ancient Greece. Cambridge, MA: Harvard University Press.

John Miles Foley. Traditional Oral Epic: The Odyssey, Beowulf, and the Serbo-Croatian Return Song. Berkeley: University of California Press. Rpt. 1993. 
Foley 1991

Grabman 1909-11 - Immanent Art. From Structure to Meaning in Traditional Oral Epic. Bloomington: Indiana University Press.

Martin Grabman. Die Geschichte der scholastischen Methode. 2 vols. Berlin: Akademie Verlag. Rpt. 1956.

Gumbrecht and Pfeiffer 1988 Hans Ulrich Gumbrecht and K. Ludwig Pfeiffer, eds. Materialität der Kommunikation. Suhrkamp Taschenbuch Wissenschaft, 750. Frankfurt/Main: Suhrkamp.

Gumbrecht and Pfeiffer 1993 Schrift. Materialität der Zeichen. Reihe A, Band 12. Munich: Wilhelm Fink Verlag.

Havelock 1963

Eric A. Havelock. Preface to Plato. Cambridge, MA: Belknap Press.

Havelock 1978 The Greek Concept of Justice: From Its Shadow in Homer to Its Substance in Plato. Cambridge, MA: Harvard University Press.

Havelock 1982

Jewett 1971

Robert Jewett. Paul's Anthropological Terms: A Study of Their Use in Conflict Settings. Leiden: E. J. Brill.

Kelber 1983

Werner H. Kelber. The Oral and the Written Gospel: The Hermeneutics of Speaking and Writing in the Synoptic Tradition, Mark, Paul, and Q. Philadelphia: Fortress Press.

Kennedy 1980

George A. Kennedy. Classical Rhetoric and its Christian and Secular Tradition from Ancient to Modern Times. Chapel Hill: University of North Carolina Press.

Kennedy 1983

King 1991

\section{Princeton: Princeton University Press.}

Nathalia King. "The Mind's Eye and the Forms of Thought: Classical Rhetoric and the Composition of Augustine's Confessions." Unpub. Ph.D. dissertation, New York University. 
Kinneavy 1987

Klein 1960

Murphy 1974

Ong 1967

Ong 1977

Ong 1982

Ong 1983

Padel 1991

Patterson 1985

Ricoeur 1977

Saenger 1982

Sanders 1977
James L. Kinneavy. Greek Rhetorical Origins of Christian Faith. New York: Oxford University Press.

J. Klein. "Ockham, Wilhelm von (ca. 1285-1349)." Die Religion in Geschichte und Gegenwart. 3rd ed. vol. 4: 1556-62.

James J. Murphy. Rhetoric in the Middle Ages: A History of Rhetorical Theory from Saint Augustine to the Renaissance. Berkeley: University of California Press.

Walter J. Ong. The Presence of the Word: Some Prolegomena for Cultural and Religious History. New Haven: Yale University Press. Rpt. Minneapolis: University of Minnesota Press, 1981.

Interfaces of the Word: Studies in the Evolution of Consciousness and Culture. Ithaca: Cornell University Press.

. Orality and Literacy. The Technologizing of the Word. London and New York: Methuen. . "Foreword." In The Present State of Scholarship in Historical and Contemporary Rhetoric. Ed. by Winifred Bryan Horner. Columbia: University of Missouri Press. pp. 1-9.

Ruth Padel. In and Out of the Mind: Greek Images of the Tragic Self. Princeton: Princeton University Press.

Richard Patterson. Image and Reality in Plato's Metaphysics. Indianapolis: Hackett.

Paul Ricoeur. The Rule of Metaphor: Multi-disciplinary Studies of the Creation of Meaning in Language. Trans. by Robert Czerny et al. Toronto: University of Toronto Press.

Paul Saenger. "Silent Reading: Its Impact on Late Medieval Script and Society." Viator, 13:367-414.

E.P. Sanders. Paul and Palestinian Judaism: A Comparison of Patterns of Religion. Philadelphia: Fortress Press. 
Segal 1962

Smith 1974

Stock 1990

Stowers 1981

Swearingen 1991

Troll 1990

Wuellner 1977

Yates 1966
Charles P. Segal. "Gorgias and the Psychology of the Logos." Harvard Studies in Classical Philology, 66:99155.

Robert W. Smith. The Art of Rhetoric in Alexandria: Its Theory and Practice in the Ancient World. The Hague: Martinus Nijhoff.

Brian Stock. Listening for the Text: On the Uses of the Past. Baltimore: Johns Hopkins University Press.

Stanley Kent Stowers. The Diatribe and Paul's Letter to the Romans. SBL Dissertation Series, 57. Chico, CA: Scholars Press.

C. Jan Swearingen. Rhetoric and Irony: Western Literacy and Western Lies. New York: Oxford University Press.

Denise A. Troll. "The Illiterate Mode of Written Communication: The Work of the Medieval Scribe." In Oral and Written Communication: Historical Approaches. Ed. by Richard Leo Enos. Newbury Park: Sage Publications. pp. 96-125.

Wilhelm Wuellner. "Paul's Rhetoric of Argumentation in Romans: An Alternative to the Donfried-Karris Debate Over Romans." Catholic Biblical Quarterly, 38:330-51. Rpt. in The Romans Debate, ed. by K. P. Donfried. Minneapolis, MN: Augsburg, pp. 152-74; 2nd ed., Peabody, MA: Hendrickson, 1991, pp. 128-46.

Frances A. Yates. The Art of Memory. Chicago: University of Chicago Press. 